Florida International University FIU Digital Commons

3-20-2018

\title{
Ambient Light: Essays on Marriage, Motherhood, and Mental Health
}

Bonnie Losak

Florida International University, blosa001@fiu.edu

DOI: $10.25148 /$ etd.FIDC004072

Follow this and additional works at: https://digitalcommons.fiu.edu/etd

Part of the Nonfiction Commons

\section{Recommended Citation}

Losak, Bonnie, "Ambient Light: Essays on Marriage, Motherhood, and Mental Health" (2018). FIU Electronic Theses and Dissertations. 3668.

https://digitalcommons.fiu.edu/etd/3668

This work is brought to you for free and open access by the University Graduate School at FIU Digital Commons. It has been accepted for inclusion in FIU Electronic Theses and Dissertations by an authorized administrator of FIU Digital Commons. For more information, please contact dcc@fiu.edu. 


\title{
FLORIDA INTERNATIONAL UNIVERSITY
}

\author{
Miami, Florida
}

AMBIENT LIGHT: ESSAYS ON MARRIAGE, MOTHERHOOD, AND MENTAL HEALTH

A thesis submitted in partial fulfillment of

the requirements for the degree of

MASTER OF FINE ARTS

in

CREATIVE WRITING

By

Bonnie Losak

2018 
To: Dean Michael R. Heithaus

College of Arts, Sciences and Education

This thesis, written by Bonnie Losak, and entitled, Ambient Light: Essays on Marriage, Motherhood, and Mental Health, having been approved in respect to style and intellectual content, is referred to you for judgment.

We have read this thesis and recommend that it be approved.

$\begin{array}{r}\hline \text { John Dufresne } \\ \hline \text { Maneck Daruwala } \\ \hline \text { Julie Marie Wade, Major Professor }\end{array}$

Date of Defense: March 20, 2018

The thesis of Bonnie Losak is approved.

Dean Michael R. Heithaus

College of Arts, Sciences and Education

Andres G. Gil

Vice President for Research and Economic Development and Dean of the University Graduate School

Florida International University, 2018 
@Copyright 2018 by Bonnie Losak

All rights reserved 


\section{DEDICATION}

For my three children, whose lives fill these pages, and who fill my life with joy. 


\section{ACKNOWLEDGMENTS}

First, an abundance of thanks to Julie Marie Wade, whose enthusiasm alone has carried me over the finish line.

Many thanks also to John Dufresne, Campbell McGrath, Denise Duhamel, and the other professors in whose classes and under whose guidance I composed many of the essays and poems that are contained this work.

Thanks to Victor and Lourdes for their technical help and to Justine for understanding when Mom was holed up at home writing, instead of trekking to the beach with her. And thanks to Natalia for having favorite words too.

Thanks to my niece, Lisa Beth, who was always one of my first readers and most ardent supporters.

Finally, a huge thanks to you, Dad, for not understanding why my work has not yet been published in The New Yorker. 


\section{ABSTRACT OF THE THESIS}

AMBIENT LIGHT: ESSAYS ON MARRIAGE, MOTHERHOOD, AND MENTAL HEALTH

by

Bonnie Losak

Florida International University, 2018

Miami, Florida

Professor Julie Wade, Major Professor

AMBIENT LIGHT: ESSAYS ON MARRIAGE, MOTHERHOOD, AND

MENTAL HEALTH is a collection of ten personal and lyric essays interspersed with poems that speak to the subject or tone of the essay that follows. These essays examine the narrator's experiences as mother, wife, and daughter, and explore the manner in which the different roles bleed into one another. The narrator's impending divorce and the events that coalesce around it shape these essays into a coherent whole.

In the spirit of Brenda Miller's lyric essays, the essays collected in AMBIENT LIGHT: ESSAYS ON MARRIAGE, MOTHERHOOD, AND MENTAL HEALTH, use rich, imagistic language to tell of places and times both reflective and speculative in nature. They speak to the all-too-common dilemma of balancing motherhood with a demanding professional life, while also considering less ordinary issues, such as one child's mental health challenges and another's run-ins with the law. 


\section{TABLE OF CONTENTS}

\section{CHAPTER}

PAGE

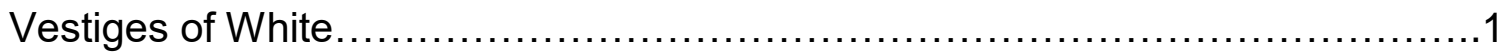

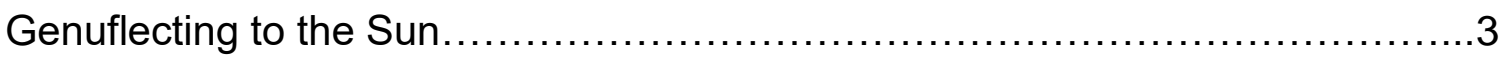

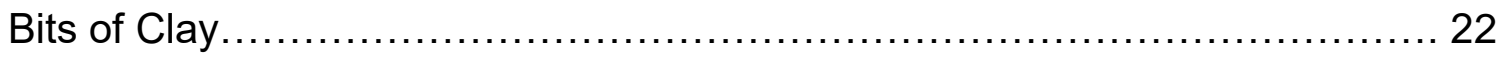

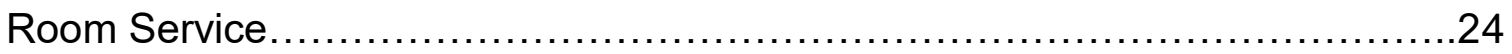

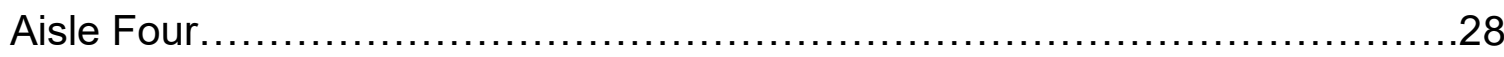

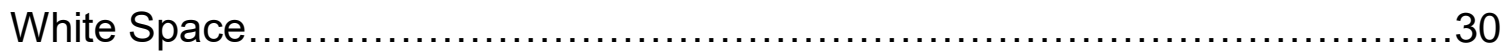

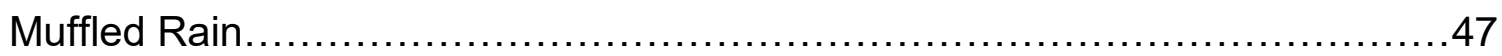

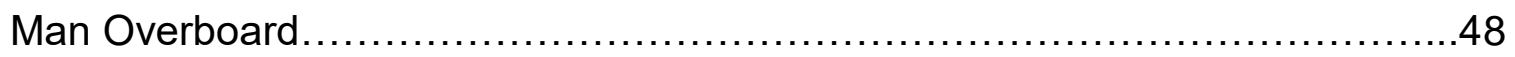

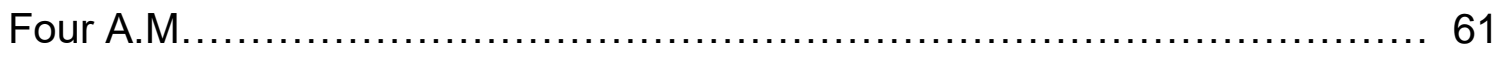

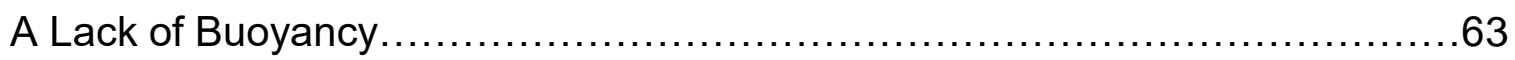

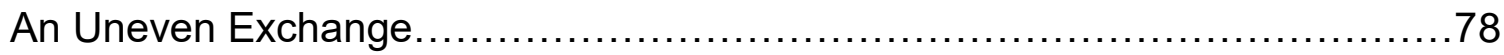

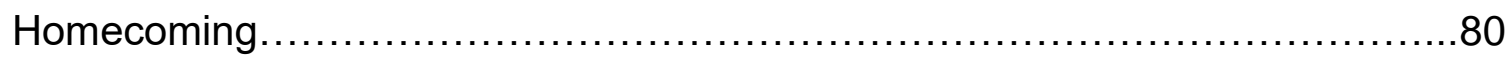

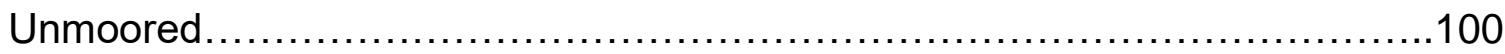

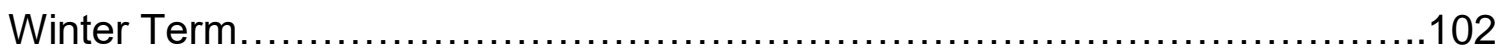

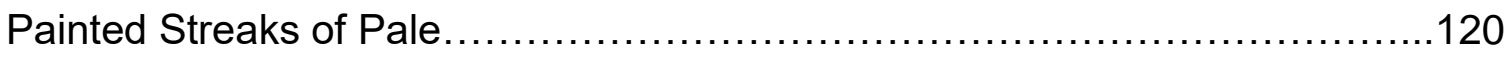

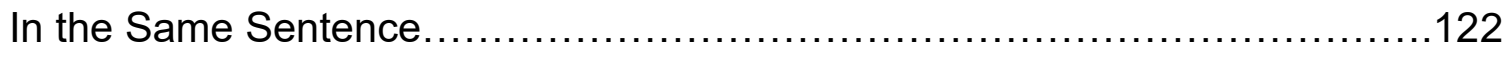

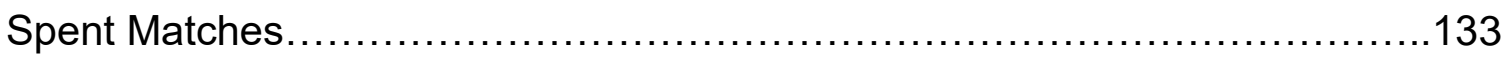

Tuesday He Brings Me Flowers .............................................. 135

The Marks of Their Departure .............................................. 145

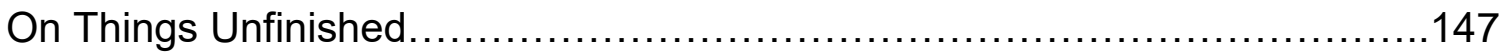


About the Author.. 


\section{Vestiges of White}

(after Spanish Trilogy)

From the heat, look! that rises in visible waves

just above the pavement-(and from you)

from storefront windows lined with papier mache

masks heavy with paint and despair (and from you)

from the whistle of a distant train lurching

toward an unfamiliar station (and from you)

from you and from all you have stolen to forge

this illusion; from the slack breathing

of white pines that skirt an unfinished structure

set at the edge of town, not yet a farmhouse or a silo-

from you and from every fire smoldering

near an unsuspecting forest, planted with red oak

and dotted with false acacias; from the very flesh

you shaped to fashion this illusion, this lie, this void,

from foreign scents and pianos thick with dust,

from young women peddling trinkets on wet sidewalks, women with coiled hair and skirts they rarely change, from watercolors that hang in abandoned hotels,

from so much that is lost and from you, 
there lingers just this: a shifting space

of ambient light. 
Genuflecting to the Sun

It's Christmas night, 2013 and my older daughter, Tessa, and I are sitting on our front porch in a pair of Adirondack chairs her dad and I purchased more than two decades earlier with Green Stamps that were doled out by a local supermarket as a loyalty incentive. The left leg of my chair is wobbly. Paint is peeling from its armrests. By this time next year it will have been hauled to the side of the street and lain in repose on one side, soon to be collected by the City of Miami Beach Waste Department, and carted off to the dump.

I imagine my rickety chair heaped alongside beach umbrellas that no longer provide shade and living room sofas with exposed springs. Maybe the chair will be sought out and probed by a man whose pregnant wife would like to sit on their small balcony in the evenings. She is no longer comfortable leaning on the railing when the two seek refuge from the heat on the unadorned slab of cement that juts out from their third-floor apartment. The man examines the discarded chair, jostles the wood with his calloused hands. He can fix it, he decides, make it sturdy again. Maybe he'll even bring the chair inside once the baby comes. His wife can use the wide chair to nurse the infant, he thinks. He smiles to himself, imagining her with their child, resting in the newly refurbished chair in front of a whirring box fan they cannot yet afford to buy.

It's late and our neighborhood, a modest, mad-made island less than a mile and one-half from the beach, should be peaceful. And it is, sort of. There's no tch tch tch of outboard engines puttering back from a day at the sandbar, no 
pop band serenading an all-night party to which we haven't been invited, no kids yelping in back-yard pools.

Even on our covered front porch, Tessa and I speak in whispers. This is despite the fact that whispering is wholly unnecessary because inside our meloncolored two story home, Tessa's father, my husband, is screaming. At me. l've come outside to escape his fury. Tessa has followed me to provide comfort or more likely, because she also feels the need to flee. Enrique is drunk- again. Is it any different from last time?

Tessa, and her sister too, know to approach the house cautiously on Friday evenings. If the stereo is audible from inside the car, they don't go to the front door. Instead, the three of us will arrange to take dinner at Shucker's, or maybe the Chinese buffet. Afterward we might go to an outdoor mall where we'll coo at babies in strollers, ball gown-style dresses in store windows, and other people's dogs. If we're lucky, by the time we get home, Enrique will be asleep on the couch, or at least subdued. Maybe the liquor is no longer coursing through his system, his eyes no longer glazed over. If the music is still blaring, it means he's still drunk. What is it with loud music and drinking anyway? Someone goes to the computer. Maybe alcohol causes a temporary hearing loss, she says.

Was this December outburst any different from last time? I consider. The drunken rages have been going on for so many years, l've lost count. Enrique often doesn't remember the extent of his rampage by the next morning. $\mathrm{He}$ wakes up apologetic. He washes dishes, brings flowers. But it's no use. My eyes 
are streaked red with exhaustion, and I am unable to either forget or forgive the insults he can't remember making.

\section{"Mom," Tessa says.}

I don't respond. Am I crying? I can't remember. The wind picks up, and a browning palm frond threatens to break free from the tree that has spawned it. Later, when it hits the front lawn with a thwack, I startle, but Tessa just laughs.

I study Tessa's profile. She has cropped her hair to chin-length. It's the color of chocolate ice cream just scooped into a cone. In high school she dyed it green, then blue. Once, maybe her sophomore year in college, she completely shaved it off. It was a statement. I'm pretty sure it was intended to announce in bold script, "I am a lesbian. Do you get it now?"

Some did. Others pretended they didn't. I think they're pretending still.

Tessa interrupts my thoughts that spin in circles and then get stuck, like car tires in the rising tide at Crescent Beach.

"Why don't the two of you just get divorced already?" Tessa asks, her tone solemn, demanding.

Now I'm definitely crying, tears mottling uneven lines onto blush-contoured cheeks, sobs working their way into rasping coughs that are released from somewhere beyond my mouth. My body shakes with a sound created outside of thoughts and sanity, a place distant from flesh and body. 